\title{
Phenolic Phytoalexins in Rice: Biological Functions and Biosynthesis
}

\author{
Man-Ho Cho ${ }^{1, *}$ and Sang-Won Lee ${ }^{1,2, *}$ \\ Received: 10 October 2015; Accepted: 1 December 2015; Published: 7 December 2015 \\ Academic Editor: Marcello Iriti \\ 1 Graduate School of Biotechnology, Kyung Hee University, Yongin 17104, Korea \\ 2 Department of Plant Molecular Systems Biotechnology \& Crop Biotech Institute, Kyung Hee University, \\ Yongin 17104, Korea \\ * Correspondence: manhocho@khu.ac.kr (M.-H.C.); swlee6803@khu.ac.kr (S.-W.L.); \\ Tel.: +82-31-201-2127 (M.-H.C.); +82-31-204-3473 (S.-W.L.)
}

\begin{abstract}
Phytoalexins are inducible secondary metabolites possessing antimicrobial activity against phytopathogens. Rice produces a wide array of phytoalexins in response to pathogen attacks and environmental stresses. With few exceptions, most phytoalexins identified in rice are diterpenoid compounds. Until very recently, flavonoid sakuranetin was the only known phenolic phytoalexin in rice. However, recent studies have shown that phenylamides are involved in defense against pathogen attacks in rice. Phenylamides are amine-conjugated phenolic acids that are induced by pathogen infections and abiotic stresses including ultra violet (UV) radiation in rice. Stress-induced phenylamides, such as $\mathrm{N}$-trans-cinnamoyltryptamine, $\mathrm{N}$ - $p$-coumaroylserotonin and $\mathrm{N}$-cinnamoyltyramine, have been reported to possess antimicrobial activities against rice bacterial and fungal pathogens, an indication of their direct inhibitory roles against invading pathogens. This finding suggests that phenylamides act as phytoalexins in rice and belong to phenolic phytoalexins along with sakuranetin. Phenylamides also have been implicated in cell wall reinforcement for disease resistance and allelopathy of rice. Synthesis of phenolic phytoalexins is stimulated by phytopathogen attacks and abiotic challenges including UV radiation. Accumulating evidence has demonstrated that biosynthetic pathways including the shikimate, phenylpropanoid and arylmonoamine pathways are coordinately activated for phenolic phytoalexin synthesis, and related genes are induced by biotic and abiotic stresses in rice.
\end{abstract}

Keywords: biotic/abiotic stress; phenolic phytoalexins; phenylamide; plant defense mechanism; rice; sakuranetin

\section{Introduction}

Environmental stresses and plant diseases are undoubtedly critical factors in crop production and associated losses [1,2]. Rice is a major staple crop that provides a large portion of human nutrition [3]. In the period of 2001-2003, actual losses of rice production worldwide due to biotic stresses were estimated at $37.4 \%$ of the attainable yield, of which pathogens caused $10.8 \%$ of the losses [1]. To cope with biotic and abiotic stresses, plants have developed a wide array of defense responses, of which the production of phytoalexins is among their chemical defense repertoire $[4,5]$.

Phytoalexins are inducible secondary metabolites possessing antimicrobial activity toward phytopathogens $[4,5]$. Since the diterpenoids momilactone A and B were identified as phytoalexins in rice leaves infected with blast fungus (Magnaporthe oryzae), many diterpenoid phytoalexins, including momilactones, phytocassanes and oryzalexins, have been identified from pathogen-infected rice [6-13]. The flavonoid sakuranetin is highly accumulated in rice leaves in response to blast infection and possesses strong antimicrobial activity against blast fungus, which suggests that it is an 
important phytoalexin in rice [14]. Although sakuranetin was identified as a phenolic phytoalexin, most rice phytoalexins are diterpenoid compounds, and research efforts have mainly focused on diterpenoid phytoalexins [15-19].

Until very recently, sakuranetin had been considered the only phenolic phytoalexin in rice. However, recent studies have shown that several phenylamides (amine-conjugated phenolic compounds) play a role as defense related agents exhibiting antimicrobial activity against rice pathogens [20-23]. This observation suggests that, along with sakuranetin, phenylamides are members of phenolic phytoalexins in rice. While the chemical nature and biosynthesis of diterpenoid phytoalexins have been extensively studied and reviewed $[13,15,17-19]$, there has been no comprehensive review of phenolic phytoalexins in rice. In this review, we summarize recent progress in rice phenolic phytoalexin research.

\section{Phenolic Phytoalexins in Rice}

\subsection{Chemical Nature of Phenolic Phytoalexins in Rice}

Sakuranetin is a well-known phenolic phytoalexin in rice and is a 7-methylated flavanone (Figure 1) [14,22]. In addition to sakuranetin, a group of defense-related phenolic compounds possessing antimicrobial activity was recently identified from pathogen-infected and UV-treated rice leaves [20-23]. $\quad N$-p-Coumaroylserotonin (CouSer), $N$-feruloyltryptamine (FerTrp) and $\mathrm{N}$-feruyolserotonin (FerSer) were identified from rice leaves infected with fungal pathogens, such as blast fungus and rice brown spot fungus Bipolaris oryzae (Figure 1) [20,21]. N-cinnamoyltyramine (CinTyr), N-benzoyltryptamine (BenTrp) and $N$-cinnamoyltryptamine (CinTrp) were identified from UV irradiated rice leaves (Figure 1) [22,23]. These phenolic compounds belong to the phenolics subclass phenylamides, which represent the conjugated form of phenolic acids such as trans-cinnamic, $p$-coumaric and ferulic acids with mono- or poly-amines [24-26]. Amine moieties found in rice phenylamide phytoalexins include arylmonoamines tyramine, tryptamine and serotonin (Figure 1).<smiles>COc1cc(O)c2c(c1)OC(c1ccc(O)cc1)CC2=O</smiles>

Sakuranetin<smiles>O=C(NCCc1c[nH]c2ccccc12)c1ccccc1</smiles>

$N$-Benzoyltryptamine<smiles>N#C/C=C/c1ccccc1</smiles><smiles>[R]c1ccc2[nH]cc(CCNC(=O)/C=C/c3ccc([R3])c([R])c3)c2c1</smiles>

$N$-Cinnamoyltryptamine; $N$-Feruloyltryptamine; $\mathrm{R}_{1}=\mathrm{H}, \mathrm{R}_{2}=\mathrm{H}, \mathrm{R}_{\mathbf{3}}=\mathrm{H}$ $N-p$-Coumaroylserotonin; $N$-Feruloylserotonin;

$$
\mathrm{R}_{1}=\mathrm{H}, \mathrm{R}_{2}=\mathrm{OCH}_{3}, \mathrm{R}_{3}=\mathrm{OH}
$$$$
\mathrm{R}_{1}=\mathrm{OH}, \mathrm{R}_{2}=\mathrm{H}, \mathrm{R}_{3}=\mathrm{OH}
$$$$
\mathrm{R}_{1}=\mathrm{OH}, \mathrm{R}_{2}=\mathrm{OCH}_{3}, \mathrm{R}_{3}=\mathrm{OH}
$$

Figure 1. Antimicrobial phenolic compounds, including the methylflavonoid sakuranetin and phenylamides that accumulate in rice in response to biotic and/or abiotic stresses. 


\subsection{Induced Phenolic Phytoalexin Contents in Rice}

Accumulation of a diverse array of diterpenoid phytoalexins in rice is induced by pathogen infections, such as blast-infection [6-12]. The flavonoid sakuranetin was suggested to be an important rice phytoalexin that is highly accumulated in blast-infected rice leaves compared to diterpenoid phytoalexins [14]. The sakuranetin content in blast-infected rice leaves was reported to be $50.6-100 \mu \mathrm{g} / \mathrm{g}$ fresh leaves (Table 1) [14,27], while the content of momilactones and phytocassanes in blast-infected rice leaves was 8.5-43.2 and 1.9-37.7 $\mu \mathrm{g} / \mathrm{g}$ fresh leaves, respectively [12]. Oryzalexins and ent-10-oxodepressin contents in blast-infected rice leaves were $2.11-16.8$ and $2.48 \mu \mathrm{g} / \mathrm{g}$ fresh leaves, respectively [11,27]. In addition to pathogen attack, UV radiation was reported to be an important elicitor of most rice phytoalexins $[7,10,11,23,28]$. The sakuranetin content in UV-irradiated rice leaves was reported to range from $22.1-135 \mu \mathrm{g} / \mathrm{g}$ fresh leaves (Table 1), which is comparable to the diterpenoid phytoalexin content in UV-treated rice leaves ranged 1.5-139 $\mathrm{\mu g} / \mathrm{g}$ fresh leaves $[14,23,27,28]$. The sakuranetin content in $\mathrm{CuCl}_{2}$ and jasmonic acid (JA) treated rice was reported to be approximately 0.8 and $4 \mu \mathrm{g} / \mathrm{g}$ fresh leaves, respectively (Table 1) [29].

Phenylamides are known to be involved in plant defense by contributing to cell wall reinforcement and providing direct toxic effects against pathogens and insects [26,27,30-35]. It was recently reported that the infection of rice brown spot fungus B. oryzae results in accumulation of phenylamides, including CouSer, FerTrp and FerSer, in infected rice leaves [20,21]. Rice leaves with decreased accumulation of CouSer and FerSer from treatment with (S)- $\alpha$-(fluoromethyl)tryptophan (S- $\alpha \mathrm{FMT})$, an inhibitor of L-tryptophan decarboxylase (TDC), were more severely damaged by $B$. oryzae infection than those not treated with the inhibitor, suggesting that phenylamide metabolites participate in rice defense against B. oryzae [21]. The accumulation of FerSer was also reported to be induced in rice leaves by blast infection and methyl jasmonate treatment [20]. Like most rice phytoalexins, the accumulation of phenylamides in rice leaves is induced by UV radiation [22,23]. CouSer, CinTyr, BenTrp and CinTrp were induced by UV irradiation in rice leaves [22,23]. In UV-treated rice leaves, accumulation of phenylamides reached maximum levels one or two days after UV treatment [23]. The phenylamide content in UV-treated rice is comparable with diterpenoid phytoalexin content $[23,27,28]$ with the maximum amounts of UV-induced phenylamides ranging from 32.7-104.2 $\mathrm{\mu g} / \mathrm{g}$ fresh leaves (Table 1) [23].

Table 1. Accumulation of phenolic phytoalexins in pathogen-infected and UV-treated rice leaves.

\begin{tabular}{|c|c|c|c|c|c|}
\hline \multicolumn{2}{|l|}{ Phytoalexins } & \multirow{2}{*}{$\begin{array}{l}\text { Content }{ }^{\text {a }}(\mu \mathrm{g} / \mathrm{g} \\
\text { Fresh Weight) }\end{array}$} & \multirow{2}{*}{ Elicitor } & \multirow{2}{*}{ Rice Cultivar } & \multirow{2}{*}{ References } \\
\hline Classes & Compounds & & & & \\
\hline \multirow{6}{*}{ Flavonoid } & \multirow{6}{*}{ Sakuranetin } & $\sim 100$ & M. oryzae & Aichiasahi & [14] \\
\hline & & 50.6 & M. oryzae & Koshihikari & [27] \\
\hline & & 135 & UV & Koshihikari & [27] \\
\hline & & 22.1 & UV & Dongjin & [23] \\
\hline & & $\sim 0.8$ & $\mathrm{CuCl}_{2}$ & Nipponbare & [29] \\
\hline & & $\sim 4$ & JA & Nipponbare & [29] \\
\hline \multirow{5}{*}{ Phenylamides } & CinTyr & 49.3 & UV & Dongjin & [23] \\
\hline & BenTrp & 65.7 & UV & Dongjin & [23] \\
\hline & CinTrp & 32.7 & UV & Dongjin & [23] \\
\hline & CouSer & 104.2 & UV & Dongjin & [23] \\
\hline & FerSer & 3.2 & B. oryzae & Nipponbare & [20] \\
\hline
\end{tabular}

${ }^{\text {a }}$ Maximum phytoalexin content in rice leaves after pathogen infection or UV irradiation.

\subsection{Antimicrobial Activity and Other Defensive Roles of Phenolic Phytoalexins in Rice}

Antimicrobial activities of rice phytoalexins have been investigated with rice pathogens, in particular, blast fungus. Rice diterpenoid phytoalexins inhibit $M$. oryzae spore germination and germ tube growth with half-inhibition concentration $\left(\mathrm{IC}_{50}\right)$ values of $1-35$ and $2-103 \mu \mathrm{g} / \mathrm{mL}$, 
respectively $[8,10-12,36]$. Sakuranetin was found to exhibit strong inhibitory activity against germ tube growth of blast fungus with an $\mathrm{IC}_{50}$ of $5 \mu \mathrm{g} / \mathrm{mL}$, which is more potent than diterpenoid phytoalexins [14]. Sakuranetin also inhibited mycelial growth of blast fungus with an $\mathrm{IC}_{50}$ of $6.44 \mu \mathrm{g} / \mathrm{mL}$ (Table 1) [23]. The $\mathrm{IC}_{50}$ of the diterpenoid oryzalexin D against mycelial growth of blast fungus was reported to be $230 \mu \mathrm{g} / \mathrm{mL}$ [37]. In addition to anti-blast fungal activity, a recent study determined that sakuranetin has broad antimicrobial activity against diverse rice fungal and bacterial pathogens [23]. Sakuranetin inhibited mycelial growth of B. oryzae and sheath blight fungus Rhizoctonia solani with $\mathrm{IC}_{50}$ values of 19.05 and $54.04 \mu \mathrm{g} / \mathrm{mL}$, respectively (Table 2). Growth of rice bacterial pathogens causing bacterial grain rot (Burkholderia glumae), blight (Xanthomonas oryzae pv. Oryzae, Xoo), and leaf streak (X. oryzae pv. oryzicola, Xoc) diseases was also reported to be inhibited by sakuranetin with $\mathrm{IC}_{50}$ values of $8.22,19.95$ and $2.36 \mu \mathrm{g} / \mathrm{mL}$, respectively (Table 2), suggesting that it is a broad-spectrum antimicrobial agent against bacterial pathogens as well as fungal pathogens [23].

Table 2. Antimicrobial activity of rice phenolic phytoalexins against phytopathogens.

\begin{tabular}{|c|c|c|c|c|c|}
\hline Phytoalexins & Pathogens & & Antimicrobial Activity & $\mathrm{IC}_{50}(\mu \mathrm{g} / \mathrm{mL})$ & References \\
\hline \multirow{7}{*}{ Sakuranetin } & \multirow{4}{*}{ Fungal } & \multirow{2}{*}{ M. oryzae } & Inhibition of germ tube growth & 5 & [14] \\
\hline & & & Inhibition of mycelial growth & 6.44 & [23] \\
\hline & & R. solani & Inhibition of mycelial growth & 54.04 & [23] \\
\hline & & B. oryzae & Inhibition of mycelial growth & 19.05 & [23] \\
\hline & \multirow{3}{*}{ Bacterial } & $\begin{array}{l}\text { X. oryzae pv. } \\
\text { oryzae }\end{array}$ & Inhibition of cell growth & 19.95 & [23] \\
\hline & & $\begin{array}{l}\text { X. oryzae pv. } \\
\text { oryzicola }\end{array}$ & Inhibition of cell growth & 2.36 & {$[23]$} \\
\hline & & B. glumae & Inhibition of cell growth & 8.22 & [23] \\
\hline \multirow[t]{2}{*}{ CinTyr } & \multirow[t]{2}{*}{ Bacterial } & $\begin{array}{l}\text { X. oryzae pv. } \\
\text { oryzae }\end{array}$ & Inhibition of cell growth & 21.96 & [23] \\
\hline & & $\begin{array}{l}\text { X. oryzae pv. } \\
\text { oryzicola }\end{array}$ & Inhibition of cell growth & 3.18 & [23] \\
\hline \multirow[t]{2}{*}{ BenTrp } & \multirow[t]{2}{*}{ Bacterial } & $\begin{array}{l}\text { X. oryzae pv. } \\
\text { oryzae }\end{array}$ & Inhibition of cell growth & 34.76 & [23] \\
\hline & & $\begin{array}{l}\text { X. oryzae pv. } \\
\text { oryzicola }\end{array}$ & Inhibition of cell growth & 3.72 & [23] \\
\hline \multirow{4}{*}{ CinTrp } & Fungal & B. oryzae & Inhibition of mycelial growth & 26.92 & {$[23]$} \\
\hline & \multirow{3}{*}{ Bacterial } & $\begin{array}{l}\text { X. oryzae pv. } \\
\text { oryzae }\end{array}$ & Inhibition of cell growth & 24.34 & [23] \\
\hline & & $\begin{array}{l}\text { X. oryzae pv. } \\
\text { oryzicola }\end{array}$ & Inhibition of cell growth & 2.45 & [23] \\
\hline & & B. glumae & Inhibition of cell growth & 41.09 & [23] \\
\hline \multirow[t]{2}{*}{ CouSer } & Fungal & $\begin{array}{l}\text { Aciculosporium } \\
\text { take }\end{array}$ & Inhibition of mycelial growth & 84 & [33] \\
\hline & Bacteria & $\begin{array}{l}\text { X. oryzae pv. } \\
\text { oryzicola }\end{array}$ & Inhibition of cell growth & 54.54 & {$[23]$} \\
\hline FerTrp & Fungal & $\begin{array}{l}\text { Fusarium } \\
\text { culmorum }\end{array}$ & Inhibition of mycelial growth & 22 & [35] \\
\hline
\end{tabular}

Phenylamides have been isolated from many plant species and their antimicrobial properties have been reported against bacterial and fungal phytopathogens, suggesting that they play a key role as phytoalexins in plant defense mechanisms [30-35]. However, little is known about antimicrobial phenylamides in rice. A recent study showed that stress-induced rice phenylamides possess antimicrobial activities against rice bacterial and fungal pathogens [23]. CinTrp, identified in UV-irradiated rice leaves, inhibited mycelial growth of $B$. oryzae with an $\mathrm{IC}_{50}$ of $26.92 \mu \mathrm{g} / \mathrm{mL}$ and exhibited antibacterial activity against $B$. glumae, Xoo, and Xoc, with $\mathrm{IC}_{50}$ values ranging from 2.45-41.09 $\mu \mathrm{g} / \mathrm{mL}$ (Table 2) [23]. UV-induced CinTyr and BenTrp were determined to possess antibacterial activities against Xoo and Xoc (Table 2) [23]. CouSer is induced in rice leaves by both UV-irradiation and B. oryzae infection and inhibits the growth of Xoc with an $\mathrm{IC}_{50}$ of $54.54 \mu \mathrm{g} / \mathrm{mL}$ (Table 2) [23]. CouSer was also identified as a bamboo plant phytoalexin, showing antimicrobial activity against witches' broom fungus Aciculosporium take with an $\mathrm{IC}_{50}$ value of $84 \mu \mathrm{g} / \mathrm{mL}$ (Table 2) [33]. FerTrp isolated from the roots of Allium species was reported to have antifungal 
activity against Fusarium culmorum [35]. Phytopathogen and abiotic stress-induced synthesis and antimicrobial properties of rice phenylamides suggest that they are a new class of rice phytoalexins comprising phenolic phytoalexins such as sakuranetin.

In addition to their function as antimicrobial agents, a number of studies have suggested that phytoalexins play diverse roles in plant defense responses to biotic and abiotic stresses [5]. Diterpenoid momilactones A and B were isolated as allelochemicals from rice seed husk and were later identified as phytoalexins because of their blast-induced biosynthesis and antifungal activity $[6,38]$. Biosyntheses of momilactones $\mathrm{A}$ and $\mathrm{B}$ and most rice diterpenoid phytoalexins were also reported to be induced by UV exposure $[7,10,11,23,28]$. The flavonoid phytoalexin sakuranetin was induced by UV irradiation as a major flavonoid aglycone in UV-treated rice leaves [14,22,23]. Phenolics, such as flavonoids and phenolic acids, are well known to act as sunscreen against harmful UV and scavengers of reactive oxygen species (ROS) in plants [39-41]. Due to the amine and phenolic acid moieties, phenylamides act as antioxidants that scavenge free radicals [26]. Accumulation of phenylamides, such as ferulylputrescine and cinnamoylputrescine, were reported to be associated with the formation of free radicals in tobacco and beans under excess water and high temperature stresses, respectively [42]. FerTrp and CinTyr were found to exhibit radical scavenging activity [43]. In rice leaves, phenylamide phytoalexins were produced upon UV exposure [22,23]. The accumulation of sakuranetin and phenylamide phytoalexins in UV-irradiated rice leaves suggests a defensive role of rice phytoalexins in UV-induced oxidative stress [22].

As a physical barrier, the cell wall is important in plant defense against biotic and abiotic stresses. During the defense response to pathogen attacks and wounding, the cell wall is reinforced by deposition of cell wall biopolymers, such as callose and lignin, to prevent the entrance and propagation of invading pathogens $[5,44,45]$. Wound-induced synthesis of phenylamides, such as feruloyltyramine and $p$-coumaroyltyramine, and their deposition in the cell wall are well known in wounded potato tissues, suggesting that they contribute to defensive biopolymers [46-48]. In rice, tryptamine, serotonin and tryptamine derived phenylamides induced by $B$. oryza infection were reported to be deposited in the cell wall of lesion tissues [20,21]. Treatment with the tryptamine biosynthesis inhibitor $S$ - $\alpha$ FMT suppressed the accumulation of tryptamine and its phenolic-conjugates and decreased the deposition of these materials in lesion tissues, which resulted in inhibitor treated leaves being susceptible to B. oryzae infection [21]. This finding indicates that pathogen-induced rice phenylamides are involved in the defense response through reinforcement of the cell wall near infection sites in addition to their phytoalexin function.

Allelochemicals are produced in plant tissues and are released into the environment, suppressing the growth and establishment of neighboring plants [49-51]. Allelopathic properties of diterpenoid phytoalexins, such as momilactones $\mathrm{A}$ and $\mathrm{B}$, have been well established in rice $[37,52,53]$. Momilactones are secreted from rice roots into the environment and play a role as allelochemicals $[52,53]$. Phenolic acids, such as $p$-coumaric acid, ferulic acid and caffeic acid, were also isolated from the roots of allelopathic rice cultivars and were identified as allelochemicals [54-56]. The phenolic acid moieties in phenylamide phytoalexins suggest that they likely act as allelochemicals in rice. In addition to UV and pathogen induced accumulation of phenylamide phytoalexins in rice leaves, CinTrp and BenTrp were isolated from rice roots without external stimulus [57]. A recent study also demonstrated that the phenylamide CinTyr isolated from rice acts as an allelochemical that inhibited root and hypocotyl growth of cress, barnyard grass, and red sprangletop [58]. This result suggests that phenylamide phytoalexins are potential allelochemicals in rice.

\section{Biosynthesis of Rice Phenolic Phytoalexins}

During stress-induced production of sakuranetin and phenylamide phytoalexins, a series of metabolic pathways are potentially activated in rice tissues. The biosynthetic pathways implicated in rice phenolic phytoalexin synthesis include the shikimate pathway for aromatic L-amino acids (AAs) and the phenylpropanoid pathway for phenolic acid moieties in phenylamides and 
sakuranetin [22,39,40,59-61]. In plants, most genes for these pathway enzymes exist as multigene families, of which a set of genes are induced and implicated in biotic and abiotic stress-triggered synthesis of phenolic phytoalexins in rice $[22,59,62,63]$. Recently, functional studies of genes involved in phenolic phytoalexin synthesis have been performed with rice. Here, we summarize the induced biosynthetic pathways and genes for rice phenolic phytoalexin biosynthesis in response to various stresses, in particular UV irradiation and phytopathogen attack.

\subsection{Shikimate and Phenylalanine Biosynthetic Pathway}

Aromatic AAs are building blocks for protein synthesis and serve as common precursors for plant secondary metabolites, such as phenolics and nitrogen containing compounds [60]. The shikimate pathway, an early biosynthetic pathway for aromatic AAs, is activated in plants under stress conditions (Figure 2) [22,60,64]. The shikimate pathway synthesizes chorismate, a common intermediate for aromatic AAs, from phosphoenol pyruvate and erythrose 4-phosphate [60]. Activation of the shikimate pathway by pathogen attack was demonstrated with the metabolomic analysis of M. oryzae infected rice leaves [64]. A recent transcriptomic analysis also showed that shikimate pathway genes were induced in rice leaves in response to UV radiation [22]. A set of shikimate pathway genes including 3-deoxy-D-arabino-heptulosonate 7-phosphate synthase (DAHPS, Os07g42960), 3-dehydroquinate synthase (DHQS, Os09g36800), 3-dehydroquinate dehydratase/shikimate dehydrogenase (DHQDT/SDH, Os01g27750 and Os12g34874), shikimate kinase (SK, Os06g12150 and Os02g51410), and chorismate synthase (CS, Os03g14990), are immediately induced by UV treatment prior to the accumulation of sakuranetin and phenylamide phytoalexins, which implies the possible involvement of these genes in phytoalexin biosynthesis in rice (Table 3) [22]. Chorismate is subsequently converted to L-phenylalanine (Phe) and L-tyrosine (Tyr) by chorismate mutase (CM), prephenate aminotransferase (PAT), and arogenate dehydratase (ADT) or arogenate dehydrogenase [60]. Induction of $C M$ (Os01g55870) and ADT (Os10g37980) were observed in rice leaves in response to UV treatment (Table 3) [22]. Direct evidence for a phytoalexin synthesis-related function of shikimate pathway genes and Phe and Tyr biosynthetic genes in rice has not yet been reported.

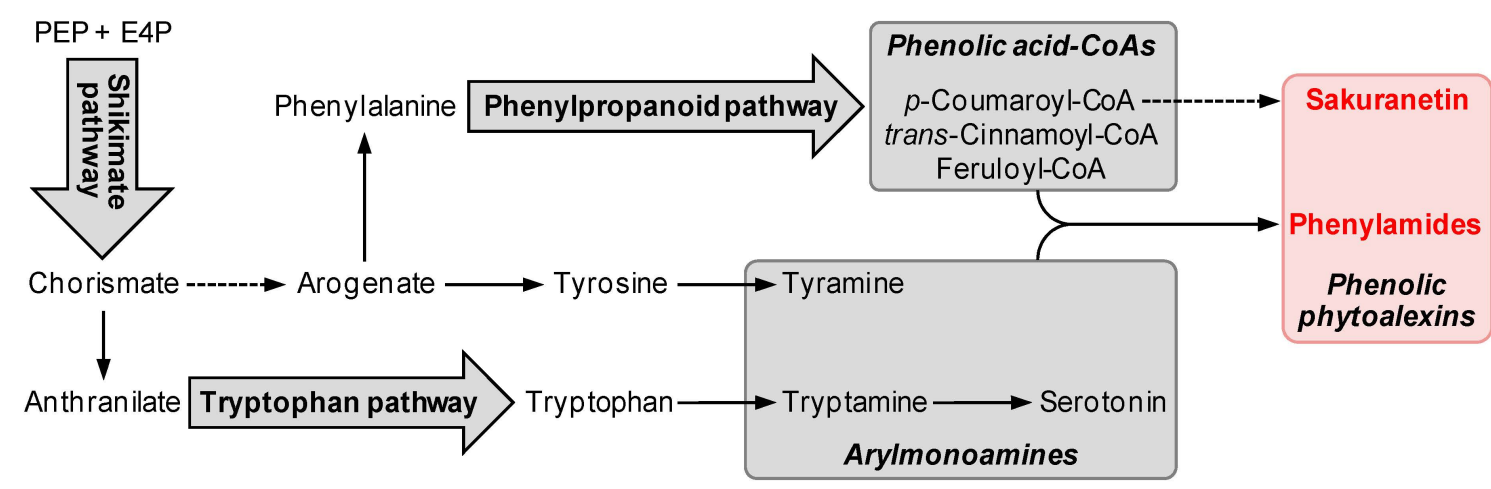

Figure 2. Biotic and abiotic stress-induced metabolic pathways for phenolic phytoalexin biosynthesis in rice. The shikimate, phenylpropanoid and tryptophan pathways are coordinately activated by biotic and abiotic stresses to synthesize phenolic phytoalexins in rice. Phenolic acid-CoAs, such as $p$-coumaroyl-, trans-cinnamoyl- and feruloyl-CoAs, serve as intermediates in the formation of sakuranetin and phenylamide phytoalexins. Arylmonoamines, such as tryptamine, tyramine and serotonin, are conjugated with phenolic acid-CoAs to form phenylamide phytoalexins. Dashed arrows indicate multiple enzymatic steps. PEP; phosphoenol pyruvate, E4P; erythrose 4-phosphate. 


\subsection{Phenylpropanoid Pathway}

In plants, phenolic compounds, such as lignin, soluble phenolics and flavonoids, are primarily derived from Phe through the phenylpropanoid pathway $[39,40,59,61]$. Phe is deaminated to form trans-cinnamate by phenylalanine ammonia lyase (PAL). trans-Cinnamate is further converted to a diverse array of phenylpropanoid metabolites by the concerted action of phenylpropanoid pathway enzymes, including cinnamate 4-hydroxylase $(\mathrm{C} 4 \mathrm{H}), p$-coumarate 3-hydroxylase $(\mathrm{C} 3 \mathrm{H}), 4$-coumarate: CoA ligase (4CL) and caffeate O-methyltransferase (COMT). Phenylpropanoid metabolites serve as precursors for sakuranetin and phenolic moieties in phenylamide phytoalexins (Figure 2) $[22,26,61,65,66]$.

PAL is a key phenylpropanoid pathway enzyme, which participates in the biosynthesis of the defense-related hormone salicylic acid and phenolic compounds including phenolic phytoalexins [22,67]. $P A L$ genes (OSPALs) in rice consist of a large gene family with 11 members in the Michigan State University (MSU) rice genome database (version 7.0) released from the MSU Rice Genome Annotation Project [62,63]. A knockout mutant of OsPAL6 (Os02g41680) showed increased susceptibility to root-invaded M. oryzae and the almost complete disappearance of sakuranetin in the infected rice roots, which suggests a role of this pathway in disease-resistance to blast fungus and sakuranetin biosynthesis [67]. Induced expression of OsPAL6 was observed in rice roots infected with M. oryzae but not in the infected leaves. In rice leaves, two OsPALs (Os02g41630 and Os02g41650) were induced by M. oryzae infection [67]. Induced expression of these OsPALs was also observed in UV-treated rice leaves along with accumulation of sakuranetin and phenylamide phytoalexins, which suggest their role in phytoalexin biosynthesis in rice leaves [22]. Although their function in phytoalexin production was not examined, an involvement of OsPALs in the defense response against pathogens has been suggested. The deletion mutation of an OsPAL4 (Os02g41680) caused increased susceptibility to fungal and bacterial pathogens [68]. Induction of two OsPALs [PAL07 (Os04g43800) and PAL04 (Os05g35290)] was reported in rice suspension culture treated with cell wall hydrolyzates prepared from M. oryzae [69].

Hydroxy-cinnamates, such as $p$-coumarate and caffeate, are formed from trans-cinnamate by hydroxylases, such as $\mathrm{C} 4 \mathrm{H}$ and $\mathrm{C} 3 \mathrm{H}$. In rice, functional $\mathrm{C} 4 \mathrm{H}$ and $\mathrm{C} 3 \mathrm{H}$ genes have yet to be identified. Four cytochrome P450s similar to $\mathrm{C} 4 \mathrm{H}$ are found in the MSU rice genome database [69]. UV-induced expression of a cytochrome P450 gene (Os2g26770) similar to C4H was observed in the microarray analysis of UV-treated rice leaves (Table 3) [22]. COMTs and caffeoyl-CoA $\mathrm{O}$-methyltransferases (CCoAOMTs) participate in the formation of methylated phenolic acid-CoAs, such as feruloyl-CoA $[59,61]$. Transcriptomic analysis of UV-treated rice leaves showed that four putative OMTs (Os11g19840, Os09g17560, Os08g06100 and Os04g01470) similar to flavonoid OMTs and COMTs are up-regulated in response to UV irradiation prior to accumulation of sakuranetin and phenylamide phytoalexins, which suggests their possible involvement in phenolic phytoalexin synthesis in rice [22].

Phenolic acid-CoAs, such as $p$-coumaroyl-CoA and feruloyl-CoA, are key branch points in phenolic metabolism. They serve as activated intermediates for flavonoid and phenylamide biosynthesis. 4CLs catalyze the ligation of CoA to phenolic acids. Five Os4CLs (Os4CL1-5) were characterized, and their roles in lignin synthesis and phenolic metabolism were investigated in rice [70,71]. In addition, $104 \mathrm{CL}$-like genes exist in the MSU rice genome database [62]. Os4CL2 (Os02g46970) is specifically expressed in the anther and is strongly induced by UV irradiation, which suggests its role in flavonoid biosynthesis [71]. In UV-treated rice leaves, activation of a 4CL-like gene (Os03g04000) expression was accompanied by an accumulation of phenolic phytoalexins, which suggests its possible involvement in phytoalexin synthesis in rice (Table 3) [22].

\subsection{Sakuranetin Biosynthesis}

Sakuranetin is the 7-methylated form of the flavanone naringenin (Figure 1) [14,22]. $p$-Coumaroyl-CoA is condensed with three molecules of malonyl-CoA to naringenin chalcone by chalcone synthase (CHS), which is then converted to the flavanone naringenin by chalcone isomerase 
(CHI) $[39,40,59]$. Thirty genes similar to CHS and seven CHI-like genes were found in the MSU rice genome database [62]. Although a recent transcriptomic analysis of UV-treated rice leaves showed activation of three OsCHSs (Os04g01354, Os07g31770 and Os11g32650) and two OsCHIs (Os02g02370 and Os11g02440) along with the accumulation of sakuranetin [22], further research is required to identify $\mathrm{OsCHS}$ and $\mathrm{OsCHI}$ genes involved in sakuranetin formation. The final step of sakuranetin formation is a methylation step of the 7-OH of the flavanone naringenin. Naringenin $\mathrm{O}$-methyltransferase (OsNOMT) for sakuranetin synthesis was purified from UV-irradiated oscomt1 rice leaves, and the corresponding gene (Os12g13800) was identified (Table 3) [29]. Expression of OsNOMT was induced by JA and UV treatment in rice leaves prior to sakuranetin accumulation [22,29]. Possible involvement of UV-induced OMTs closely related to flavonoid OMTs in sakuranetin synthesis was suggested by phytochemical and transcriptomic analyses of UV-irradiated rice leaves (Table 3) [22]; however, their definitive role in phenolic phytoalexin biosynthesis in rice needs to be further studied.

\subsection{Arylmonoamine Biosynthesis and Its Conjugation with Phenolic Acid-CoAs}

Phenylamides are formed by the conjugation of arylamines and phenolic acids [22,26,65]. Arylmonoamines found in rice phenylamide phytoalexins are tyramine, tryptamine, and its derivative serotonin (Figure 1) [20-23]. Tyramine and tryptamine are derived from Tyr and L-tryptophan (Trp), respectively. Tyr biosynthesis mostly shares the phenylalanine biosynthetic pathway and is induced in rice leaves in response to UV treatment [22,60]. The Trp biosynthetic pathway from chorismate was reported to be activated by B. oryzae and M. oryzae infection and UV irradiation [20,22].

Chorismate is converted to anthranilate by anthranilate synthase (AS), which is a heteromer composed of $\alpha(\mathrm{AS} \alpha)$ and $\beta(\mathrm{AS} \beta)$ subunits in plants [60]. The rice genome contains two AS $\alpha$ (OsASA1 and OsASA2) and two AS $\beta$ (OsASB1 and OsASB2) genes. In rice leaves, OsASA2 (Os03g15780) was induced by chitin elicitor treatment and infection with phytopathogens, such as B. oryzae, Xoo, and M. oryzae, which was accompanied by an increase in intermediates for tryptophan biosynthesis [20,72,73]. Both OsASB1 (Os04g38950) and OsASB2 (Os03g50880) were induced in rice by UV treatment and infection with pathogens, including B. oryzae and Xoo $[20,22,72,73]$. Induction of OsASB2 was also observed in the rice spotted leaf 5 (spl5) mutant, which showed enhanced resistance to pathogens [74].

Anthranilate is further converted to Trp by the serial action of anthranilate phosphoribosyltransferase (APT), phosphoanthranilate isomerase (PAI), indole-3-glycerol phosphate synthase (IGPS), and Trp synthase (TS) [60]. APT (Os03g03450) and PAI (Os02g16630) expressions were found to be induced by pathogen attack [73]. Induced expression of an IGPS gene (Os09g08130) was observed in UV-treated rice leaves and in the rice spl5 mutant [22,74]. TS is composed of $\alpha$ $(\mathrm{TS} \alpha)$ and $\beta$ (TS $\beta)$ subunits. The transcript level of TSA (Os07g08430) and TS $\alpha$ protein abundance were increased in UV-treated and pathogen-infected rice leaves [22,73,75]. TSA expression was also increased in the rice spl5 mutant [74]. TSB1 (Os08g04180) was induced by UV treatment and pathogen attack in rice leaves [22,73]. The induction of TSB2 (Os06g42560) was also observed in UV-treated rice leaves [22].

Trp decarboxylase (TDC) and Tyr decarboxylase (TYDC), which belong to a family of aromatic AA decarboxylases (AADCs), catalyze the conversion of tryptophan and tyrosine to the corresponding arylmonoamines, tryptamine and tyramine, respectively, [76]. Induced TDC activity by $M$. oryzae infection was reported in sekiguchi lesion (sl) mutant rice [77]. The AADC gene (Os08g04540) was induced in UV treated rice leaves [22]. This AADC was heterologously expressed in E. coli, and the recombinant enzyme exhibited TDC activity [78]. Over-expression of this gene led to increased tryptamine and serotonin levels in transgenic rice plants [78].

Serotonin, 5-hydroxytryptamine, is formed from tryptamine by tryptamine 5-hydroxylase (T5H) $[73,79]$. Rice sekiguchi lesion $(s l)$ mutants were observed to accumulate tryptamine, and the $S L$ 
gene was identified as the cytochrome P450 monooxygenase gene (Os12g16720) encoding T5H [79]. Expression of $S L$ was induced by chitin elicitation and M. oryzae infection [79]. This T5H gene was also induced in UV or cadmium-treated rice leaves $[22,80]$. This result suggests that the T5H encoding $S L$ gene is involved in serotonin formation during stress responses.

Table 3. Stress-induced genes tentatively involved in phenolic phytoalexin biosynthesis in rice.

\begin{tabular}{|c|c|c|c|c|}
\hline Pathways/Enzyme & No. ${ }^{a}$ & Gene Name $^{b}$ (or Locus ID ${ }^{c}$ ) & Elicitors (or Evidence) & References \\
\hline \multicolumn{5}{|l|}{ Shikimate pathway } \\
\hline$D A H P S$ & 7 & Os07g42960 & UV & [22] \\
\hline$D H Q S$ & 1 & Os09g36800 & UV & {$[22]$} \\
\hline$D H Q D T / S D H$ & 6 & Os01g27750, Os12g34874 & UV & [22] \\
\hline SK & 10 & Os06g12150, Os02g51410 & UV & {$[22]$} \\
\hline$C S$ & 1 & Os03g14990 & UV & [22] \\
\hline$C M$ & 5 & Os01g55870 & UV & {$[22]$} \\
\hline$A D T$ & 12 & Os10g37980 & UV & [22] \\
\hline \multicolumn{5}{|l|}{$\begin{array}{c}\text { Phenylpropanoid } \\
\text { pathway }\end{array}$} \\
\hline \multirow[t]{4}{*}{$P A L$} & 11 & OsPAL6 (Os02g41680) & M. oryzae & [67] \\
\hline & & $\begin{array}{l}\text { OsPAL1 (Os02g41630), } \\
\text { OsPAL8 (Os02g41650) }\end{array}$ & M. oryzae, UV & {$[22,67]$} \\
\hline & & OsPAL4 (Os02g41680) & $\begin{array}{c}\text { Mutation causes disease } \\
\text { susceptibility }\end{array}$ & {$[68]$} \\
\hline & & $\begin{array}{c}\text { PAL07 (Os04g43800), PAL04 } \\
\text { (Os05g35290) }\end{array}$ & $\begin{array}{l}\text { Cell hydrolyzates from } \\
\text { M. oryzae }\end{array}$ & [69] \\
\hline $\mathrm{C} 4 \mathrm{H}$ & 4 & Os2g 26770 & UV & [22] \\
\hline \multirow[t]{2}{*}{$4 C L$} & 15 & Os4CL2 (Os02g46970) & UV & [71] \\
\hline & & Os03g04000 & UV & {$[22]$} \\
\hline COMT & & $\begin{array}{l}\text { Os11g19840, Os09g17560, } \\
\text { Os08g06100, Os04g01470 }\end{array}$ & UV & [22] \\
\hline \multicolumn{5}{|l|}{$\begin{array}{l}\text { Sakuranetin } \\
\text { biosynthesis }\end{array}$} \\
\hline CHS & 30 & $\begin{array}{c}\text { Os04g01354, Os07g31770, } \\
\text { Os11g32650 }\end{array}$ & UV & {$[22]$} \\
\hline $\mathrm{CHI}$ & 7 & Os02g02370, Os11g02440 & UV & [22] \\
\hline NOMT & & OsNOMT (Os12g13800) & UV, JA & {$[22,29]$} \\
\hline \multicolumn{5}{|l|}{ Tryptophan pathway } \\
\hline$A S \alpha$ & 2 & OsASA2 (Os03g15780) & B. oryzae, chitin, Xoo, M. oryzae & {$[20,72,73]$} \\
\hline$A S \beta$ & 2 & $\begin{array}{l}\text { OsASB1 (Os04g38950), } \\
\text { OsASB2 (Os03g50880) }\end{array}$ & UV, B. oryzae, Xoo, M. oryzae & {$[20,23,73]$} \\
\hline$A P T$ & 2 & Os03g03450 & Xoo, M. oryzae & [73] \\
\hline PAI & 1 & Os02g16630 & Хоo, M. oryzae & [73] \\
\hline IGPS & 3 & Os09g08130 & $\begin{array}{l}\text { UV, induced in the spl5 } \\
\text { mutant }\end{array}$ & {$[22,74]$} \\
\hline$T S \alpha$ & 5 & TSA (Os07g08430) & $\begin{array}{l}\mathrm{UV} \text {, induced in the spl5 } \\
\text { mutant, Xoo, M. oryzae }\end{array}$ & {$[22,73-75]$} \\
\hline$T S \beta$ & 2 & TSB1 (Os08g04180) & UV, Xoo, M. oryzae & {$[22,73]$} \\
\hline & & TSB2 (Os06g42560) & UV & {$[22]$} \\
\hline \multicolumn{5}{|l|}{$\begin{array}{l}\text { Phenylamide } \\
\text { biosynthesis }\end{array}$} \\
\hline$A A D C$ & 7 & Os08g04540 & UV, M. oryzae & {$[22,77]$} \\
\hline $\mathrm{T} 5 \mathrm{H}$ & & SL (Os12g16720) & M. oryzae, chitin, $\mathrm{CdCl}_{2}, \mathrm{UV}$ & {$[22,79,80]$} \\
\hline Acyltransferase & & $\begin{array}{l}\text { Os11g42370, Os04g09260, } \\
\text { Os09g37180, Os04g56900, } \\
\text { Os01g42880, Os02g39850, } \\
\text { Os01g09010, Os07g36560 }\end{array}$ & 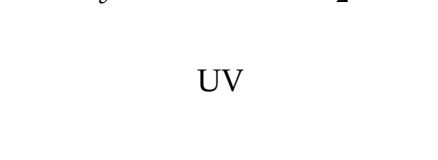 & [22] \\
\hline
\end{tabular}

${ }^{a}$ Number of annotated genes in each gene family; ${ }^{b}$ Name of gene in references; ${ }^{\mathrm{c}}$ Gene locus identifiers in the MSU rice genome database (version 7.0) [62]. 
Phenylamides are formed by the conjugation of arylmonoamines with phenolic acid-CoAs catalyzed by acyltransferases such as BAHD acyltransferases and tyramine: $N$-hydroxycinnamoyl transferase-like enzymes [22,65,81]. Little is known about functional acyltransferases involved in phenylamide phytoalexin biosynthesis in rice. Microarray analysis of UV-treated rice leaves showed that several acyltransferases belonging to clades VI and V of the BAHD acyltransferase family are immediately induced in response to UV treatment along with the induction of arylamine and phenolic acid-CoA biosynthetic genes (Table 3) [22]. The clades VI and V of the BAHD family contain $N$-acyltransferases [81]. Thus, the UV-induced BAHD acyltransferases have been suggested to be involved in phenylamide phytoalexin biosynthesis in rice [22]. A definitive role of stress-induced BAHD acyltransferase genes in phenylamide phytoalexin synthesis requires further study in rice.

\section{Conclusions}

It has long been known that rice phytoalexins are mostly diterpenoid compounds. Recent studies, however, have shown that phenolic compounds play an important role in disease resistance of rice as phytoalexins, which include a range of phenylamides and sakuranetin. The phenolic phytoalexins are also implicated in rice defense against biotic and abiotic stresses through the reinforcement of cell walls and scavenging ROS, as well as exhibiting an allelopathic property. In addition to their biological functions in plants, rice phytoalexins show a diverse range of health beneficial properties. Sakuranetin exhibits antibiotic activity to Helicobacter pylori and allergy preventive activity $[82,83]$. Phenylamide phytoalexins, such as CinTrp and CouSer, are reported to have antimicrobial properties against pathogenic bacteria, as well as antiinflammatory and antiatherogenic effects $[43,84,85]$. Thus, more research is required to clearly understand the biological roles and biosynthetic rotes of phenolic phytoalexins in rice, as well as for their biotechnological applications.

Acknowledgments: This research was supported by a grant from the Next-Generation BioGreen 21 Program (Project No: PJ01107501), Rural Development Administration, Republic of Korea.

Author Contributions: Man-Ho Cho and Sang-Won Lee conceived the work and wrote the article.

Conflicts of Interest: The authors declare no conflict of interest.

\section{References}

1. Oerke, E.C. Crop losses to pests. J. Agric. Sci. 2006, 144, 31-43. [CrossRef]

2. Chakraborty, S.; Newton, A.C. Climate change, plant diseases and food security: An overview. Plant Pathol. 2011, 60, 2-14. [CrossRef]

3. Khush, G. Productivity improvements in rice. Nutr. Rev. 2003, 61, 114-116. [CrossRef]

4. Ahuja, I.; Kissen, R.; Bones, A.M. Phytoalexins in defense against pathogens. Trends Plant Sci. 2012, 17, 73-90. [CrossRef] [PubMed]

5. Großkinsky, D.K.; van der Graaff, E.; Roitsch, T. Phytoalexin transgenics in crop protection-Fairy tale with a happy end? Plant Sci. 2012, 195, 54-70. [CrossRef] [PubMed]

6. Cartwright, D.; Langcake, P.; Pryce, R.J.; Leworthy, D.P.; Ride, J.P. Chemical activation of host defense mechanisms as a basis for crop protection. Nature 1977, 267, 511-513. [CrossRef]

7. Cartwright, D.W.; Langcake, P.; Pryce, R.J.; Leworthy, D.P.; Ride, J.P. Isolation and characterization of two phytoalexins from rice as momilactones A and B. Phytochemistry 1981, 20, 535-537. [CrossRef]

8. Akatsuka, T.; Kodama, O.; Sekido, H.; Kono, Y.; Takeuchi, S. Novel phytoalexins (Oryzalexins A, B, and C) isolated from rice blast leaves infected with Pyricularia oryzae. Part I: Isolation, characterization and biological activities of oryzalexins. Agric. Biol. Chem. 1985, 49, 1689-1694. [CrossRef]

9. Sekido, H.; Endo, T.; Suga, R.; Kodama, O.; Akatsuka, T.; Kono, Y.; Takeuchi, S. Oryzalexin D (3,7-(+)-sandaracopimaradiene), a new phytoalexin isolated from blast-infected rice leaves. J. Pestic. Sci. 1986, 11, 369-372. [CrossRef]

10. Kato, H.; Korama, O.; Akatsuka, T. Oryzalexin E, a diterpene phytoalexin from UV-irradiated rice leaves. Phytochemistry 1993, 33, 79-81. [CrossRef] 
11. Kato, H.; Kodama, O.; Akatsuka, T. Oryzalexin F, a diterpene phytoalexin from UV-irradiated rice leaves. Phytochemistry 1994, 36, 299-301. [CrossRef]

12. Koga, J.; Shimura, M.; Oshima, K.; Ogawa, N.; Yamauchi, T.; Ogasawara, N. Phytocassanes A, B, C and D, novel diterpene phytoalexins from rice, Oryza sativa L. Tetrahedron 1995, 51, 7907-7918. [CrossRef]

13. Schmelz, E.A.; Huffaker, A.; Sims, J.W.; Christensen, S.A.; Lu, X.; Okada, K.; Peters, R.J. Biosynthesis, elicitation and roles of monocot terpenoid phytoalexins. Plant J. 2014, 79, 659-678. [CrossRef] [PubMed]

14. Kodama, O.; Miyakawa, J.; Akatsuka, T.; Kiyosawa, S. Sakuranetin, a flavanone phytoalexin from ultraviolet-irradiated rice leaves. Phytochemistry 1992, 31, 3807-3809. [CrossRef]

15. Peters, R.J. Uncovering the complex metabolic network underlying diterpenoid phytoalexin biosynthesis in rice and other cereal crop plants. Phytochemistry 2006, 67, 2307-2317. [CrossRef] [PubMed]

16. Okada, A.; Shimizu, T.; Okada, K.; Kuzuyama, T.; Koga, J.; Shibuya, N.; Nojiri, H.; Yamane, H. Elicitor induced activation of the methylerythritol phosphate pathway toward phytoalexins biosynthesis in rice. Plant Mol. Biol. 2007, 65, 177-187. [CrossRef] [PubMed]

17. Toyomasu, T. Recent advances regarding diterpene cyclase genes in higher plants and fungi. Biosci. Biotechnol. Biochem. 2008, 72, 1168-1175. [CrossRef] [PubMed]

18. Okada, K. The biosynthesis of isoprenoids and the mechanisms regulating it in plants. Biosci. Biotechnol. Biochem. 2011, 75, 1219-1225. [CrossRef] [PubMed]

19. Yamane, H. Biosynthesis of phytoalexins and regulatory mechanisms of it in rice. Biosci. Biotechnol. Biochem. 2013, 77, 1141-1148. [CrossRef] [PubMed]

20. Ishihara, A.; Hashmoto, Y.; Tanaka, C.; Dubouzet, J.G.; Nakao, T.; Matsuda, F.; Nishioka, T.; Miyagawa, H.; Wakasa, K. The tryptophan pathway is involved in the defense responses of rice against pathogenic infection via serotonin production. Plant J. 2008, 54, 481-495. [CrossRef] [PubMed]

21. Ishihara, A.; Nakao, T.; Mashimo, Y.; Murai, M.; Ichimaru, N.; Tanaka, C.; Nakajima, H.; Wakasa, K.; Miyagawa, H. Probing the role of tryptophan-derived secondary metabolism in defense responses against Bipolaris oryzae infection in rice leaves by a suicide substrate of tryptophan decarboxylase. Phytochemistry 2011, 72, 7-13. [CrossRef] [PubMed]

22. Park, H.L.; Lee, S.W.; Jung, K.H.; Hahn, T.R.; Cho, M.H. Transcriptomic analysis of UV-treated rice leaves reveals UV-induced phytoalexin biosynthetic pathways and their regulatory networks in rice. Phytochemistry 2013, 96, 57-71. [CrossRef] [PubMed]

23. Park, H.L.; Yoo, Y.; Hahn, T.R.; Bhoo, S.H.; Lee, S.W.; Cho, M.H. Antimicrobial activity of UV-induced phenylamides from rice leaves. Molecules 2014, 19, 18193-18151. [CrossRef] [PubMed]

24. Martin-Tunguy, J.; Cabanne, F.; Perdrizet, E.; Martin, C. The distribution of hydroxycinnamic acid amides in flowering plants. Phytochemistry 1978, 17, 1927-1928. [CrossRef]

25. Martin-Tunguy, J. The occurrence and possible function of hydroxycinnamoyl acid amides in plants. Plant Growth Regul. 1985, 3, 381-399. [CrossRef]

26. Edreva, A.M.; Velikova, V.B.; Tsonev, T.D. Phenylamides in plants. Russ. J. Plant Physiol. 2007, 54, $287-301$. [CrossRef]

27. Inoue, Y.; Sakai, M.; Yao, Q.; Tanimoto, Y.; Toshima, H.; Hasegawa, M. Identification of a novel casbane-type diterpene phytoalexin, ent-10-oxodepressin, from rice leaves. Biosci. Biotechnol. Biochem. 2013, 77, 760-765. [CrossRef] [PubMed]

28. Kodama, O.; Suzuki, T.; Miyakawa, J.; Akatsuka, T. Ultraviolet-induced accumulation of phytoalexins in rice leaves. Agric. Biol. Chem. 1988, 52, 2469-2473. [CrossRef]

29. Shimizu, T.; Lin, F.; Hasegawa, M.; Okada, K.; Nojiri, H.; Yamane, H. Purification and identification of naringenin 7-o-methyltransferase, a key enzyme in biosynthesis of flavonoid phytoalexin sakuranetin in rice. J. Biol. Chem. 2012, 287, 19315-19325. [CrossRef] [PubMed]

30. Newman, M.A.; von Roepenack-Lahaye, E.; Parr, A.; Daniels, M.J.; Dow, J.M. Induction of hydroxycinnamoyl-tyramine conjugates in pepper by Xanthomonas campestris, a plant defense response activated by hrp gene-dependent and hrp gene-independent mechanisms. Mol. Plant Microbe Interact. 2001, 14, 785-792. [CrossRef] [PubMed]

31. Von Roepenack-Lahaye, E.; Newman, M.A.; Schornack, S.; Hammond-Kosack, K.E.; Lahaye, T.; Jones, J.D.G.; Daniels, M.J.; Dow, J.M. p-Coumaroylnoradrenaline, a novel plant metabolite implicated in tomato defense against pathogens. J. Biol. Chem. 2003, 278, 43373-43383. [CrossRef] [PubMed] 
32. Ramos, T.; El Bellaj, M.; El Idrissi-Tourane, A.; Daayf, F.; El Hadrami, I. Les Phénolamides des rachis de palmes, composants de réaction de défense du palmier dattier vis-à-vis de Fusarium oxysporum f.sp. albedinis, agent causal du bayoud. J. Phytophathol. 1997, 145, 487-493. [CrossRef]

33. Tanaka, E.; Tanaka, C.; Mori, N.; Kuwahara, Y.; Tsuda, M. Phenylpropanoid amides of serotonin accumulate in witches' broom diseased bamboo. Phytochemistry 2003, 64, 965-969. [CrossRef]

34. Von Roepenack, E.; Parr, A.; Schulze-Lefert, P. Structural analyses and dynamics of soluble cell wall-bound phenolics in a broad spectrum resistance to the powdery mildew fungus in barley. J. Biol. Chem. 1998, 273, 9013-9022. [CrossRef]

35. Fattorusso, E.; Lanzotti, V.; Taglialatela-Scafati, O. Antifungal N-feruloyl amides from roots of two Allium species. Plant Biosyst. 1999, 133, 199-203. [CrossRef]

36. Koga, J.; Ogawa, N.; Yamauchi, T.; Kikuchi, M.; Ogasawara, N.; Shimura, M. Functional moiety for the antifungal activity of phytocassane E, a diterpene phytoalexin from rice. Phytochemistry 1997, 44, 249-253. [CrossRef]

37. Sekido, H.; Akatsuka, T. Mode of action of oryzalexin D against Pyricularia oryzae. Agric. Biol. Chem. 1987, 51, 1967-1971. [CrossRef]

38. Kato, T.; Kabuto, C.; Sasaki, N.; Tsunagawa, M.; Aizawa, H.; Fujita, K.; Kato, Y.; Kitahara, Y. Momilactones, growth inhibitors from rice, Oryza sativa L. Tetrahedron. Lett. 1973, 39, 3861-3864. [CrossRef]

39. Dixon, R.A.; Paiva, N.L. Stress-induced phenylpropanoid metabolism. Plant Cell 1995, 7, $1085-1097$. [CrossRef] [PubMed]

40. Winkel-Shirley, B. Biosynthesis of flavonoids and effects of stress. Curr. Opin. Plant Biol. 2002, 5, $218-223$. [CrossRef]

41. Goufo, P.; Trindade, H. Rice antioxidants: Phenolic acids, flavonoids, anthocyanins, proanthocyanins, tocopherol, tocotrienols, $\gamma$-oryzanol, and phytic acid. Food Sci. Nutr. 2014, 2, 75-104. [CrossRef] [PubMed]

42. Edreva, A.; Yordanov, I.; Kardjieva, R.; Hadjiiska, E.; Gesheva, E. Expression of phenylamides in abiotic stress conditions. Bulg. J. Plant Physiol. 1995, 21, 15-23.

43. Georgiev, L.; Chochkova, M.; Ivanova, G.; Najdenski, H.; Ninova, M.; Mikova, T. Radical scavenging and antimicrobial activities of cinnamoyl amides of biogenic monoamines. Riv. Ital. Sost. Grasse 2012, 89, 91-102.

44. Hamann, T. Plant cell wall integrity maintenance as an essential component of biotic stress response mechanisms. Front. Plant Sci. 2012, 3, 77. [CrossRef] [PubMed]

45. Underwood, W. The plant cell wall: A dynamic barrier against pathogen invasion. Front. Plant Sci. 2012, 3, 85. [CrossRef] [PubMed]

46. Negrel, J.; Lherminier, J. Peroxidase-mediated integration of tyramine into xylem cell walls of tobacco leaves. Planta 1987, 172, 494-501. [CrossRef] [PubMed]

47. Keller, H.; Hohlfeld, H.; Wary, V.; Hahlbrock, K.; Scheel, D.; Strack, D. Changes in the accumulation of soluble and cell wall-bound phenolics in elicitor-treated cell suspension cultures and fungus-infected leaves of Solanum tuberosum. Phytochemistry 1996, 42, 389-396. [CrossRef]

48. Guillet, G.; De Luca, V. Wound-inducible biosynthesis of phytoalexin hydroxycinnamic acid amides of tyramine in tryptophan and tyrosine decarboxylase transgenic tobacco lines. Plant Physiol. 2005, 137, 692-699. [CrossRef] [PubMed]

49. Olofsdotter, M.; Jensen, L.B.; Courtois, B. Improving crop competitive ability using allelopathy-an example from rice. Plant Breed. 2002, 121, 1-9. [CrossRef]

50. Belz, R.G. Allelopathy in crop/weed interactions-an update. Pest Manag. Sci. 2007, 63, 308-326. [CrossRef] [PubMed]

51. Weston, L.A.; Mathesius, U. Flavonoids: Their structure, biosynthesis and role in the rhizosphere, including allelopathy. J. Chem. Ecol. 2013, 39, 283-297. [CrossRef] [PubMed]

52. Xu, M.; Galhano, R.; Wiemann, P.; Bueno, E.; Tiernan, M.; Wu, W.; Chung, I.M.; Gershenzon, J.; Tudzynski, B.; Sesma, A.; Peters, R.J. Genetic evidence for natural product-mediated plant-plant allelopathy in rice (Oryza sativa). New Phytol. 2012, 193, 570-575. [CrossRef] [PubMed]

53. Kato-Noguchi, H.; Peters, R.J. The role of momilactones in rice allelopathy. J. Chem. Ecol. 2013, 39, $175-185$. [CrossRef] [PubMed]

54. Rimando, A.M.; Olofsdotter, M.; Dayan, F.E.; Duke, S.O. Searching for rice allelochemicals: An example of bioassay-guided isolation. Agron. J. 2001, 93, 16-20. [CrossRef] 
55. Seal, A.N.; Pratley, J.E.; Haig, T.; An, M. Identification and quantitation of compounds in a series of allelopathic and non-allelopathic rice root exudates. J. Chem. Ecol. 2004, 30, 1647-1662. [CrossRef] [PubMed]

56. He, H.; Wang, H.; Fang, C.; Wu, H.; Guo, X.; Liu, C.; Lin, Z.; Lin, W. Barnyard grass stress up regulates the biosynthesis of phenolic compounds in allelopathic rice. J. Plant Physiol. 2012, 169, 1747-1753. [CrossRef] [PubMed]

57. Cho, J.G.; Huh, J.; Jeong, R.H.; Cha, B.J.; Shrestha, S.; Lee, D.G.; Kang, H.C.; Kim, J.Y.; Baek, N.I. Inhibition effect of phenyl compounds from the Oryza sativa roots on melanin production in murine B16-F10 melanoma cells. Nat. Prod. Res. 2015, 29, 1052-1054. [CrossRef] [PubMed]

58. Thi, H.L.; Lin, C.H.; Smeda, R.J.; Leigh, N.D.; Wycoff, W.G.; Fritschi, F.B. Isolation and identification of an allelopathic phenylethylamine in rice. Phytochemistry 2014, 108, 109-121. [CrossRef] [PubMed]

59. Naoumkina, M.A.; Zhao, Q.; Gallego-Giraldo, L.; Dai, X.; Zhao, P.X.; Dixon, R.A. Genome-wide analysis of phenylpropanoid defense pathways. Mol. Plant Pathol. 2010, 11, 829-846. [PubMed]

60. Tzin, V.; Galili, G. New insights into the shikimate and aromatic amino acids biosynthetic pathways in plants. Mol. Plant 2010, 3, 956-972. [CrossRef] [PubMed]

61. Vogt, T. Phenylpropanoid biosynthesis. Mol. Plant 2010, 3, 2-20. [CrossRef] [PubMed]

62. Rice Genome Annotation Project. Available online: http://rice.plantbiology.msu.edu/ (accessed on 29 September 2015).

63. Kawahara, Y.; de la Bastide, M.; Hamilton, J.P.; Kanamori, H.; McCombie, W.R.; Ouyang, S.; Schwartz, D.C.; Tanaka, T.; Wu, J.; Zhou, S.; et al. Improvement of the Oryza sativa Nipponbare reference genome using next generation sequence and optical map data. Rice 2013, 6, 4. [CrossRef] [PubMed]

64. Parker, D.; Beckmann, M.; Zubair, H.; Enot, D.P.; Caracuel-Rois, Z.; Overy, D.P.; Snowdon, S.; Talbot, N.J.; Draper, J. Metabolomic analysis reveals a common pattern of metabolic re-programming during invasion of three host plant species by Magnaporthe grisea. Plant J. 2009, 59, 723-737. [CrossRef] [PubMed]

65. Bassard, J.E.; Ullmann, P.; Bernier, F.; Werck-Reichhart, D. Phenolamides: Bridging polyamines to the phenolic metabolism. Phytochemistry 2010, 71, 1808-1824. [CrossRef] [PubMed]

66. Jeandet, P.; Hebrard, C.; Deville, M.A.; Cordelier, S.; Dorey, S.; Aziz, A.; Crouzet, J. Deciphering the role of phytoalexins in plant-microorganism interactions and human health. Molecules 2014, 19, 18033-18056. [CrossRef] [PubMed]

67. Duan, L.; Liu, H.; Li, X.; Xiao, J.; Wang, S. Multiple phytohormones and phytoalexins are involved in disease resistance to Magnaporthe oryzae invaded from roots in rice. Physiol. Plant. 2014, 152, 486-500. [CrossRef] [PubMed]

68. Tonnessen, B.W.; Manosalva, P.; Lang, J.M.; Baraoidan, M.; Bordeos, A.; Mauleon, R.; Oard, J.; Hulbert, S.; Leung, H.; Leach, J.E. Rice phenylalanine ammonia-lyase gene OsPAL4 is associated with broad spectrum disease resistance. Plant Mol. Biol. 2015, 87, 273-286. [CrossRef] [PubMed]

69. Giberti, S.; Bertea, C.M.; Narayana, R.; Maffei, M.E.; Forlani, G. Two phenylalanine ammonia lyase isoforms are involved in the elicitor-induced response of rice to the fungal pathogen Magnaporthe oryzae. J. Plant Physiol. 2012, 169, 249-254. [CrossRef] [PubMed]

70. Gui, J.; Shen, J.; Li, L. Functional characterization of evolutionarily divergent 4-coumarate: coenzyme A ligases in rice. Plant Physiol. 2011, 157, 574-586. [CrossRef] [PubMed]

71. Sun, H.; Li, Y.; Feng, S.; Zou, W.; Guo, K.; Fan, C.; Si, S.; Peng, L. Analysis of five rice 4-coumarate: Coenzyme A ligase enzyme activity and stress response for potential roles in lignin and flavonoid biosynthesis in rice. Biochem. Biophys. Res. Commun. 2013, 430, 1151-1156. [CrossRef] [PubMed]

72. Tozawa, Y.; Hasegawa, H.; Terakawa, T.; Wakasa, K. Characterization of rice anthranilate synthase $\alpha$-subunit genes OASA1 and OASA2. Tryptophan accumulation in transgenic rice expressing a feedback-insensitive mutant of OASA1. Plant Physiol. 2001, 126, 1493-1506. [CrossRef] [PubMed]

73. Dharmawardhana, P.; Ren, L.; Amarasinghe, V.; Monaco, M.; Thomason, J.; Ravenscroft, D.; McCouch, S.; Ware, D.; Jaiswal, P. A genome scale metabolic network for rice and accompanying analysis of tryptophan, auxin and serotonin biosynthesis regulation under biotic stress. Rice 2013, 6, 15. [CrossRef] [PubMed]

74. Jin, B.; Zhou, X.; Jiang, B.; Gu, Z.; Zhang, P.; Qian, Q.; Chen, X.; Ma, B. Transcriptomic profiling of the spl5 mutant reveals that SPL5 has a negative role in the biosynthesis of serotonin for rice disease resistance. Rice 2015, 8, 18. [CrossRef] [PubMed] 
75. Du, H.; Liang, Y.; Pei, K.; Ma, K. UV radiation-responsive proteins in rice leaves: A proteomic analysis. Plant Cell Physiol. 2011, 52, 306-316. [CrossRef] [PubMed]

76. Facchini, P.; Huber-Allanach, K.L.; Tari, L.W. Plant aromatic L-amino acid decarboxylase: Evolution, biochemistry, regulation, and metabolic engineering applications. Phytochemistry 2000, 54, 121-138. [CrossRef]

77. Ueno, M.; Shibata, H.; Kihara, J.; Honda, Y.; Arase, S. Increased tryptophan decarboxylase and monoamine oxidase activities induce Sekiguchi lesion formation in rice infected with Magnaporthe grisea. Plant J. 2003, 36, 215-228. [CrossRef] [PubMed]

78. Kang, S.; Kang, K.; Lee, K.; Back, K. Characterization of rice tryptophan decarboxylases and their involvement in serotonin biosynthesis in transgenic rice. Planta 2007, 227, 263-272. [CrossRef] [PubMed]

79. Fujiwara, T.; Maisonneuve, S.; Isshiki, M.; Mizutani, M.; Chen, L.; Wong, H.L.; Kawasaki, T.; Shimamoto, K. Sekiguchi lesion gene encodes a cytochrome P450 monooxigenase that catalyzed conversion of tryptamine to serotonin in rice. J. Biol. Chem. 2010, 285, 11308-11313. [CrossRef] [PubMed]

80. Byeon, Y.; Lee, H.Y.; Hwang, O.J.; Lee, H.J.; Lee, K.; Back, K. Coordinated regulation of melatonin synthesis and degradation genes in rice leaves in response to cadmium treatment. J. Pineal Res. 2015, 58, 470-478. [CrossRef] [PubMed]

81. D'Auria, J.C. Acyltransferases in plants: A good time to be BAHD. Curr. Opin. Plant Biol. 2006, 9, 331-340. [CrossRef] [PubMed]

82. Ogawa, Y.; Oku, H.; Iwaoka, E.; Iinuma, M.; Ishiguro, K. Allergy-preventive flavonoids from Xanthorrhoea hastilis. Chem. Pharm. Bull. 2007, 55, 675-678. [CrossRef] [PubMed]

83. Zhang, L.; Kong, Y.; Wu, D.; Zhang, H.; Wu, J.; Chen, J.; Ding, J.; Hu, L.; Jiang, H.; Shen, X. Three flavonoids targeting the $\beta$-hydroxyacyl-acyl carrier protein dehydratase from Helicobacter pylori: Crystal structure characterization with enzymatic inhibition assay. Protein Sci. 2008, 17, 1971-1978. [CrossRef] [PubMed]

84. Takii, T.; Kawashima, S.; Chiba, T.; Hayashi, H.; Hayashi, M.; Hiroma, H.; Kimura, H.; Inukai, Y.; Shibata, Y.; Nagatsu, A.; et al. Multiple mechanisms involved in the inhibition of proinflammatory cytokine production from human monocytes by $\mathrm{N}$-( $p$-coumaroyl) serotonin and its derivatives. Int. Immunopharmacol. 2003, 3, 273-277. [CrossRef]

85. Takimoto, T.; Suzuki, K.; Arisaka, H.; Murata, T.; Ozaki, H.; Koyama, N. Effect of N-(p-coumaroyl)serotonin and $N$-feruloylserotonin, major anti-atherogenic polyphenols in safflower seed, on vasodilation, proliferation and migration of vascular smooth muscle cells. Mol. Nutr. Food Res. 2011, 55, 1561-1571. [CrossRef] [PubMed]

(C) 2015 by the authors; licensee MDPI, Basel, Switzerland. This article is an open access article distributed under the terms and conditions of the Creative Commons by Attribution (CC-BY) license (http:/ / creativecommons.org/licenses/by/4.0/). 